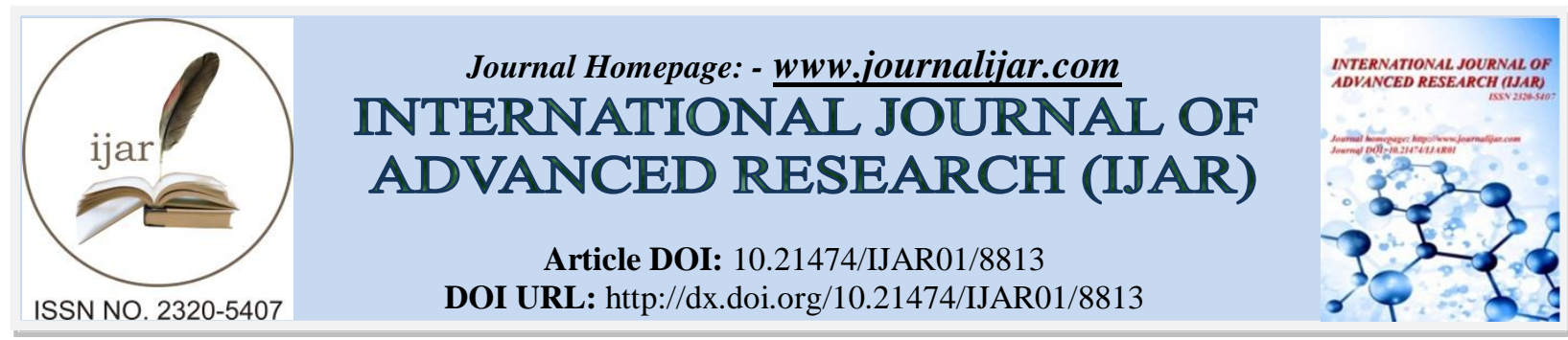

RESEARCH ARTICLE

\title{
INFLUENCE OF FOLIAR SPRAY BY ALGAE EXTRACT AND AMINO ACID ON BOTANICAL CHARACTERS AND SEED CHEMICAL COMPOSITION OF COMMON BEAN PLANT (PHASEOLUS VULGARIS L.)
}

\section{Azza M. Salama ${ }^{1}$, Samah N. Azoz ${ }^{1}$ and Ahmed M. El-Taher ${ }^{2}$.}

1. Agricultural Botany Department, Faculty of Agriculture, Cairo University, Giza, Egypt.

2. Department of Agricultural Botany, General Botany Branch, Faculty of Agriculture, Al-Azahr University, Nasr City, Cairo, Egypt.

\section{Manuscript Info}

…......................

Manuscript History

Received: 05 February 2019

Final Accepted: 07 March 2019

Published: April 2019

Key words:-

algae extract, amino acid, anatomy,

Phaseolus vulgaris L., protein.

\section{Abstract}

This study was carried out during two consecutive seasons 2017 and 2018, on common bean plants (Phaseolus vulgaris L. cv. "Giza 6") at Zawiat Riziyn village, El- Menoufiya Governorate, Egypt. In order to investigate the effect of algae extract $(1 \mathrm{ml} / \mathrm{l})$, amino acid at the concentrations of $(4,6$ and $8 \mathrm{ml} / \mathrm{l})$ and the mixture of $1 \mathrm{~m} / \mathrm{l}$ algae extract with $6 \mathrm{ml} / 1$ amino acid as a foliar application on growth, yield, anatomical structure and seeds chemical composition on the common bean plant. Results indicated that spraying the plants with the mixture significantly increased plant height, number of branches/plant, number of compound leaves/plant and plant productivity compared to the untreated plants. Also, this treatment showed promoted remarkable effect on the anatomical structure of the main stem and blade compared to the untreated plants. Generally, the maximum significant increase in any of the studied characters was detected when spraying the plants with the mixture between $1 \mathrm{ml} / 1$ algae extract with $6 \mathrm{ml} / 1$ amino acid. Spraying plants with this mixture also increased the percentages of; nitrogen, phosphor, potassium, calcium and magnesium in seeds, in addition to total crude protein and total carbohydrates percentage. Results of analyzing the amino acids in treated seeds showed high concentration of Glutamic acid; moderate of Leucine, Lysine, Phenylalanine, Tyrosine, Arginine, Alanine and Valine and low of Tryptophan.

Copy Right, IJAR, 2019,. All rights reserved.

\section{Introduction:-}

Common bean (Phaseolus vulgaris L.) is one of the most important seed food legumes in the world (Zhang et al., 2008). It contains a source of dietary, fibers calories, proteins, minerals and vitamins for millions of people in countries worldwide (Shehata et al., 2011). Egypt ranked the $6^{\text {th }}$ in world production with an average production of about 270.8 thousand tons and is the $10^{\text {th }}$ largest exporter of beans worldwide, with an average of exports about 11,000 tons, equivalent to $4 \%$ of total global crop exports (FAO, 2017).

Seaweed are known to cause many beneficial effects on plants as they contain growth promoting hormones; i.e. IAA, IBA and Cytokinins, trace elements of $\mathrm{Fe}, \mathrm{Cu}, \mathrm{Zn}, \mathrm{Co}, \mathrm{Mo}, \mathrm{Mn}$, and $\mathrm{Ni}$, vitamins and amino acids (Khan $\boldsymbol{e t}$ 
al., 2009). Seaweed extracts are biodegradable, non-toxic, non-polluting extract and nonhazardous to humans, animals and birds (Dhargalkar and Pereira, 2005). More than 15 million tons of seaweed products are used annually as nutrient supplements and biostimulants in agriculture and horticulture crop production; application of seaweed extracts enhances seed germination and seedling vigour (Economou et al., 2007). Seaweed extract could serve as an alternative biofertilizer as it is eco-friendly, cheapest, deliver substantial economic and environmental benefits to farmers (Kumar and Sahoo 2011). Exogenous application of seaweed extract has already been shown to enhance plant growth, yield and its quality (Abou El-Yazied et al., 2012).

Amino acids as organic nitrogenous compounds are well known to stimulate cell growth and acting as buffers maintaining favorable $\mathrm{pH}$ value within the plant cell as well as synthesizing other organic compounds (Opike and Rolfe 2005). Amino acids are fundamental ingredients in the process of protein synthesis, formation of plant tissue and chlorophyll synthesis. Similar effect and findings about amino acids were indicated by Abo Sedera $\boldsymbol{e t}$ al., (2010) and El-Desouky et al., (2011).

Thereby, due to the high economic value of common bean plants, (Phaseolus vulgaris L.) the present study aimed to evaluate the promoter effects of alga extract and amino acids to increase growth and seed yield parameters as well as chemical constituents of common bean cv. "Giza 6".

\section{Materials and Methods:-}

Field experiment was conducted at Zawiat Riziyn village (Private Farm), Menouf, El- Menoufiya Governorate, through the two successive seasons of 2017/2018 to study the impact of foliar application with algae extract, amino acid and the mixture between them on growth and seed yield parameters, anatomical structure, as well as chemical constituents of common bean cv. "Giza 6".

Seeds of common bean were secured from Sars El-Layan Research Station, El-Menoufiya Governorate, Egypt. The algae species Spirulina platensis was used to produce extract at the Algae Production Station of the National Research Centre (NRC, Dokki, Cairo). Macro nutrients of the used alga extract are N (10\%), P (18\%), K (10\%), Ca $(0.4 \%), \mathrm{S}(2.1 \%)$, organic matter $(16.7 \%)$ in addition to micro nutrients; $\mathrm{Mg}(0.1 \%), \mathrm{B}(0.12 \%), \mathrm{Zn}(1.7 \%), \mathrm{Fe}$ (1.32\%), Mn (1.1\%) and $\mathrm{Cu}(0.22 \%)$. A commercial amino acid was used, contains $\mathrm{N}(3 \%)$, organic matter (20\%), free amino acid (10\%), Mg (1.0\%), Fe (1.5\%), Zn (1.0\%) and Boron (3.87 ppm) with pH 6-7 and specific gravity $1.25 \mathrm{~g} / \mathrm{ml}$.

Common bean seeds were sown on $2^{\text {nd }}$ September in both seasons. After 25 days from sowing, the plants were thinned to one plant/hill. The experiment layout was randomized complete block design of three replicates. Each replicate was comprised of six plots, each plot representing one treatment. The plot including 6 rows of $2 \mathrm{~m}$ in length and $70 \mathrm{~cm}$ in between, with $15 \mathrm{~cm}$ hill spacing. Three seeds grown per hill. The treatments were; tap water "control"; alga extract at $1.0 \mathrm{ml} / \mathrm{l}$; amino acids at $4.0 \mathrm{ml} / 1,6.0 \mathrm{ml} / 1$ and $8.0 \mathrm{ml} / \mathrm{l}$; mixture of alga extract at $1 \mathrm{ml} / 1 \mathrm{with}$ amino acid at $6.0 \mathrm{ml} / \mathrm{l}$. The treatments were applied twice; at 30 and 45 days after sowing. Random samples were taken from each plot at 60 days after sowing to record the morphological characters. At harvest ( 90 days), samples were randomly taken from each pot to determine the yield characters. All plants received recommended dose of NPK fertilizers

\section{Recording of data \\ 1-Morphological characters \\ a- Plant height $(\mathrm{cm})$ \\ b- Number of branches/plant \\ c- Number of leaves/plant \\ 2- Yield characters \\ d- Number of pods/plant \\ e- Number of seeds/pod \\ f- Weight of 100 seed (g). \\ g- Seed yield/plant (g).}




\section{3- Anatomical studies}

A microscopical study was carried out to investigate the anatomical structure of the stem, represented by the $4^{\text {th }}$ internodes counted from the plant tip and the lamina of the terminal leaflet of the corresponding compound leaf at the age of 60 days, according to Nassar and El-Sahhar (1998).

\section{4- Chemical analysis of seeds}

a. Mineral elements content

At the harvest time in both seasons, samples from the mature dried seeds were subjected to determine; total nitrogen $(\mathrm{N})$ and multiplied it with 6.25 to get the crude protein in seeds. Phosphorus (P), Potassium (K), Calcium (Ca) and Magnesium (Mg) were determined and calculated as percentage of dry weight according to (A.O.A.C., 1999), at Faculty of Agriculture, Cairo University Research Park (CURP).

\section{b. Determination of amino acids}

Amino acids were extracted according to the methods described by Csomos and Simon-Sarkadi (2002) and Shalabia (2011) and measured using Amino Acid Analyzer (AAA 400 INGOS Ltd) at Faculty of Agriculture, Cairo University Research Park (CURP).

\section{5- Statistical analysis}

All collected data were subjected to statistical analysis as proposed by Gomez and Gomez (1984) and means were compared by LSD at 5\% level of probability.

\section{Results And Discussion:-}

\section{1- Morphological and yield characters:}

Foliar spray with all tested concentrations of amino acids and algae extract showed obvious effect on all vegetative growth and seed yield characters of common bean plants. The only exception was the number of seeds/pod which did not affected by any of the three tested concentrations of amino acids or algae extract in the two growing seasons. It is clear from Table (1) that the highest values of plant height, number of branches/plant and number of compound leaves/plant were recorded when plants sprayed with the mixture of alga extract at $1.0 \mathrm{ml} / 1$, with amino acid at 6.0 $\mathrm{ml} / \mathrm{l}$. The maximum increases recorded were; 40.6,54.3; 82.0,49.2; and 36.4, 36.7\% for plant height, number of branches and number of leaves more than the control plants, in $1^{\text {st }}$ and $2^{\text {nd }}$ seasons, respectively.

Data presented in Table (2) showed that the maximum significant increase in number of pods/plant, specific weight of 100 seeds/plant and seeds yield/ plant were achieved at $1 \mathrm{ml} / 1$ alga extract mixed with $6 \mathrm{ml} / \mathrm{l}$ amino acid, being 66.7, 24.1 and $73.4 \%$ more than control, respectively in the $1^{\text {st }}$ season. The same trend was observed in the $2^{\text {nd }}$ season, whereas the percentages of increases were $58.8,16.0$ and $77.5 \%$ for the same characters number. Latique $\boldsymbol{e t}$ al., (2013) reported that seaweed liquid fertilizer effect the physiological and biochemical parameters of Phaesolus vulgaris L. var Paulista under hydroponic system. Also, Raverkar et al., (2016) mentioned that foliar application of seaweed stimulate yield, nodulation and nutritional quality in Vigna radiata L. in legumes. Kocira et al., (2013) found that Ecklonia maxima extract have a positive effect on yield characters of white bean (Phaseolus vulgaris L.). El Kaoua et al., (2013) found that the seaweed extract application at lower concentration enhanced the vegetative growth on Salvia officinalis. Salama and Yousef 2015 found that foliar application of amino acids or seaweed

Table 1: Effect of algae extract, amino acid and their combination on the morphological characters of common bean plants during the two seasons; 2017 and 2018

\begin{tabular}{|c|c|c|c|c|c|c|}
\hline \multirow{3}{*}{ Treatments } & \multicolumn{6}{|c|}{ Morphological characters } \\
\hline & \multicolumn{2}{|c|}{ Plant height $(\mathrm{cm})$} & \multicolumn{2}{|c|}{ No. of branches /plant } & \multicolumn{2}{|c|}{ No. compound leaves } \\
\hline & $1^{\text {st }}$ season & $2^{\text {nd }}$ season & $1^{\text {st }}$ season & $2^{\text {nd }}$ season & $1^{\text {st }}$ season & $2^{\text {nd }}$ season \\
\hline Control & 44.10 & 46.00 & 5.00 & 6.70 & 11.00 & 11.70 \\
\hline $1 \mathrm{ml} / \mathrm{l}$. algae extract & 48.00 & 51.00 & 7.00 & 8.50 & 14.00 & 15.50 \\
\hline $4 \mathrm{ml} / \mathrm{l}$. amino acid & 49.04 & 50.00 & 6.03 & 7.20 & 12.00 & 13.60 \\
\hline $6 \mathrm{ml} / \mathrm{l}$. amino acid & 57.00 & 62.00 & 8.00 & 9.20 & 14.00 & 15.10 \\
\hline $8 \mathrm{ml} / \mathrm{l}$. amino acid & 51.00 & 55.00 & 6.00 & 7.10 & 13.00 & 14.50 \\
\hline $\begin{array}{l}6 \mathrm{ml} / \mathrm{l} . \text { amino acid }+1 \\
\mathrm{ml} / \mathrm{l} \text { algae extract }\end{array}$ & 62.00 & 71.00 & 9.10 & 10.00 & 15.00 & 16.00 \\
\hline LSD at 0.05 & 1.16 & 1.21 & 0.19 & 0.21 & 0.39 & 0.42 \\
\hline
\end{tabular}


Table 2: Effect of algae extract, amino acid and their combination on yield characters of common bean plants during the two seasons; 2017 and 2018

\begin{tabular}{|c|c|c|c|c|c|c|c|c|}
\hline \multirow[t]{2}{*}{ Treatments } & \multicolumn{2}{|c|}{ No. of pods/plant } & \multicolumn{2}{|c|}{ No. of seeds/pod } & \multicolumn{2}{|c|}{$\begin{array}{l}\begin{array}{l}\text { weight } \\
\text { seeds }(g)\end{array} \\
\text { of } 100\end{array}$} & \multicolumn{2}{|c|}{$\begin{array}{ll}\text { Seed } & \text { yield } \\
(\mathrm{g}) / \text { plant } & \\
\end{array}$} \\
\hline & $\begin{array}{l}\mathbf{1}^{\text {st }} \\
\text { season }\end{array}$ & $\begin{array}{l}2^{\text {nd }} \\
\text { season }\end{array}$ & $\begin{array}{l}\mathbf{1}^{\text {st }} \\
\text { season }\end{array}$ & $\begin{array}{l}2^{\text {nd }} \\
\text { season }\end{array}$ & $\begin{array}{l}1^{\text {st }} \\
\text { season }\end{array}$ & $\begin{array}{l}2^{\text {nd }} \\
\text { season }\end{array}$ & $\begin{array}{l}1^{\text {st }} \\
\text { season }\end{array}$ & $\begin{array}{l}2^{\text {nd }} \\
\text { Season }\end{array}$ \\
\hline Control & 9.00 & 10.70 & 2.33 & 2.40 & 42.17 & 42.50 & 12.99 & 13.91 \\
\hline $1 \mathrm{ml} / \mathrm{l}$. algae extract & 13.00 & 14.00 & 2.33 & 2.50 & 44.06 & 45.70 & 13.36 & 15.99 \\
\hline $4 \mathrm{ml} / \mathrm{l}$. amino acid & 11.00 & 12.10 & 3.00 & 3.00 & 43.97 & 44.00 & 14.51 & 16.10 \\
\hline $6 \mathrm{ml} / \mathrm{l}$. amino acid & 14.00 & 14.70 & 3.00 & 3.00 & 50.10 & 51.00 & 21.04 & 22.49 \\
\hline $8 \mathrm{ml} / \mathrm{l}$. amino acid & 13.00 & 14.10 & 3.00 & 3.00 & 46.04 & 46.10 & 17.95 & 19.50 \\
\hline $\begin{array}{l}6 \mathrm{ml} / \mathrm{l} \text {. amino acid }+1 \mathrm{ml} / \\
\text { l algae extract }\end{array}$ & 15.00 & 17.00 & 3.00 & 3.00 & 52.33 & 49.30 & 2.53 & 24.69 \\
\hline LSD at 0.05 & 1.79 & 1.60 & Ns & ns & 0.93 & 0.86 & 1.36 & 1.42 \\
\hline
\end{tabular}

extract enhanced the vegetative characters and yield components on Ocimum sanctum L. Salama et al., (2016) mentioned that the seaweed extract at the concentration of $1 \mathrm{ml} / 1$ exhibited significant promotive effect on all investigated morphological and yield characters of Stevia rebaudiana Bertoni. Boghdady et al., (2016) found that the seaweed extract at $1 \mathrm{ml} / \mathrm{l}$ induced significant promoting effect on vegetative growth and yield characters of Cicer arietinum L.

\section{2- Chemical analysis of seeds:}

a- Mineral elements content

Data presented in Table (3) influence the effect of different concentrations of amino acid, algae extract and the mixture between them as foliar application on mineral component (Nitrogen, Phosphor, Potassium, Calcium and Magnesium) as well crude protein and total carbohydrate in seeds of common bean plants. Spraying plants with mixture of $1 \mathrm{ml} / 1$ algae extract and $6 \mathrm{ml} / 1$ amino acid increased percentage of nitrogen, phosphor, potassium, calcium and magnesium in seeds by 85.2, 44.2, 17.4, 7.0 and 33.9\%, respectively as compared with control. As well, using amino acid at $6 \mathrm{ml} / 1$ mixed with $1 \mathrm{ml} / 1$ algae extract resulting in increased total crude protein and total carbohydrates percentage in seeds by 82.3 and $14.3 \%$, respectively compared with control.

These results are in harmony with those obtained by Pise and Sabale (2010). They observed that total nitrogen in fenugreek increased at the low to high concentrations of seaweeds. Also Nour et al., (2010) mentioned that foliar spray with seaweed extracts on tomato, significantly increased N, P, K and protein percentages. Rathore $\boldsymbol{e t}$ al., (2009) on soybean mentioned that foliar applications of different concentrations of seaweed extract improved nutrient uptake (N, P, K and S\%). Zodape et al.,(2008) found that okra plants sprayed with liquid seaweed fertilizers showed a significant increase of carbohydrate and protein contents. Also, significant increases in mineral content of chickpea seeds were found by using $1 \mathrm{ml} / \mathrm{l}$ seaweed extract (Boghdady et al., 2016).

\section{b- Amino acids Content}

Analysis of amino acids in common bean seeds detected nine types. These types were divided into essential amino acids i.e., Tryptophan, Leucine, Lysine, Phenylalanine and Valine, and non essential amino acids; i.e., Tyrosine, Arginine, Alanine, Glutamic acid (Table 4). The common bean seeds contain high concentration of Glutamic acid; moderate concentration of Leucine, Lysine, Phenylalanine, Tyrosine, Arginine, Alanine and Valine, and low concentration of Tryptophan.

Regarding to spraying with various concentrations of amino acids or algae extract on the amino acids content of common bean seeds, the obtained results showed that foliar spraying with mixture of $1 \mathrm{ml} / 1$ algae extract with $6 \mathrm{ml} / 1$ amino acids caused a marked increase in the concentration of Tryptophan, Phenylalanine, Tyrosine, Alanine and Valine comparing with the control plants. The increases percentage in the amino acids content reached about $154.5 \%$ in Tryptophan, $17.6 \%$ in Phenylalanine, $46.4 \%$ in Tyrosine, $13.1 \%$ in Alanine and $20.0 \%$ in Valine compared with untreated plants. Leucine acid recorded the highest value in the control plants. As for Lysine, the highest increase was observed in plants treated with $4 \mathrm{ml} / \mathrm{l}$ amino acid. It can be observed that the highest increase in Arginine and Glutamic acid were found in plants sprayed with algae extract and amino acid at $8 \mathrm{ml} / \mathrm{l}$, respectively. 
Table 3: The percentages of some mineral elements, crude protein and total carbohydrates in seeds of common bean plant cv. Giza 6 as affected by different concentrations of amino acid and algae extract and their combination in the $2^{\text {nd }}$ growing season

\begin{tabular}{|l|c|c|c|c|c|c|c|}
\hline \multicolumn{1}{|c|}{ Treatments } & N\% & P\% & K\% & Ca\% & Mg\% & $\begin{array}{c}\text { Crude } \\
\text { protein\% }\end{array}$ & $\begin{array}{c}\text { Total } \\
\text { carbohydrates\% }\end{array}$ \\
\hline Control & 0.027 & 0.113 & 0.46 & 0.85 & 0.062 & 0.17 & 4.2 \\
\hline $\mathbf{1 ~ m l / l . ~ a l g a e ~ e x t r a c t ~}$ & 0.047 & 0.144 & 0.54 & 0.86 & 0.081 & 0.29 & 4.5 \\
\hline $\mathbf{4 ~ m l / ~ l . ~ a m i n o ~ a c i d ~}$ & 0.043 & 0.135 & 0.52 & 0.88 & 0.066 & 0.27 & 4.5 \\
\hline $\mathbf{6 ~ m l}$ l. amino acid & 0.045 & 0.147 & 0.49 & 0.86 & 0.074 & 0.28 & 4.4 \\
\hline $\mathbf{8 ~ m l / l . ~ a m i n o ~ a c i d ~}$ & 0.047 & 0.145 & 0.53 & 0.87 & 0.075 & 0.29 & 4.6 \\
\hline $\begin{array}{l}\mathbf{6} \mathbf{~ m l} \text { l. amino acid +1 } \\
\mathbf{m l} \text { l algae extract }\end{array}$ & 0.050 & 0.163 & 0.54 & 0.91 & 0.082 & 0.31 & 4.8 \\
\hline
\end{tabular}

Table 4: The concentrations of amino acid in common bean seed cv. Giza 6 as affected by different concentrations of amino acid and algae extract and their combination in the $2^{\text {nd }}$ growing season

\begin{tabular}{|c|c|c|c|c|c|c|c|c|c|}
\hline \multirow[b]{2}{*}{ Treatments } & \multicolumn{5}{|c|}{ Essential amino acid } & \multicolumn{4}{|c|}{ Non essential amino acid } \\
\hline & Tryptophan & Leucine & Lysine & Phenylalanine & Valine & Arginine & Alanine & Glutamic & Tyrosine \\
\hline Control & 0.0011 & 0.0078 & 0.0057 & 0.0051 & 0.0050 & 0.0060 & 0.0038 & 0.0151 & 0.0028 \\
\hline $1 \mathrm{ml} / \mathrm{l}$. algae extract & 0.0020 & 0.0049 & 0.0044 & 0.0058 & 0.0057 & 0.0068 & 0.0040 & 0.0180 & 0.0039 \\
\hline $4 \mathrm{ml} / \mathrm{l}$. amino acid & 0.0014 & 0.0067 & 0.0061 & 0.0055 & 0.0047 & 0.0064 & 0.0036 & 0.0178 & 0.0033 \\
\hline $6 \mathrm{ml} / \mathrm{l}$. amino acid & 0.0013 & 0.0064 & 0.0060 & 0.0054 & 0.0042 & 0.0062 & 0.0034 & 0.0175 & 0.0035 \\
\hline $8 \mathrm{ml} / \mathrm{l}$. amino acid & 0.0018 & 0.0053 & 0.0050 & 0.0058 & 0.0055 & 0.0065 & 0.0039 & 0.0181 & 0.0037 \\
\hline $\begin{array}{l}6 \mathrm{ml} / \mathrm{l} . \text { amino } \\
\text { acid }+1 \mathrm{ml} / \mathrm{l} \text { algae } \\
\text { extract }\end{array}$ & 0.0028 & 0.0050 & 0.0048 & 0.0060 & 0.0060 & 0.0066 & 0.0043 & 0.0177 & 0.0041 \\
\hline
\end{tabular}

In this respect, Kalidass $\boldsymbol{e t}$ al.,(2010) indicated that seaweed liquid extract has positive effect on the content of free amino acids in Brassica nigra. Pise and Sable, 2010 found that the seaweed liquid extract has promoting effect on the content of free amino acids in Trigonella foenumgraecum. Lingakumar et al., (2006) reported that the liquid algae extract when added to the soil bed promoted amino acid content of Phaseolus mungo, Zea mays and Cyamopsis tetragonoloba. Also, Lingakumar et al., (2002) on Zea mays and Phaseolus mungo, observed that application of seaweed extract showed positive response on the total amino acid content. Foliar spraying with $1 \mathrm{ml} / \mathrm{l}$ seaweed extract caused a marked increase in the concentration of all essential and non essential amino acids in chickpea seeds comparing with the untreated control plants (Boghdady et al., 2016).

\section{3- Anatomical studies}

a- Stem anatomy

It is obvious from Table (5) and Figure (1) that foliar application with $1 \mathrm{ml} / \mathrm{l}$ algae extract mixed with $6 \mathrm{ml} / 1$ amino acid increased the main stem diameter of common bean plants by $12.33 \%$ more than control. Worthy to mention that, increasing stem diameter could be attributed to the prominent increases in most of the included tissues; cortex thickness by $11.48 \%$, phloem by $34.6 \%$ and xylem tissues by $11.66 \%$ more than control. Also, vessel diameter was increased over the control by $12.50 \%$ due to foliar spraying with $1 \mathrm{ml} / 1$ algae extract mixed with $6 \mathrm{ml} / 1$ amino acid. Nevertheless, pith diameter in treated stems was decreased by $8.16 \%$ less than that of the control.

In this respect, Salama and Yousef (2015) recorded that foliar applications with seaweed extract at concentration of $1.5 \mathrm{ml} / 1$, increased the main stem diameter, cortex, phloem and xylem tissues more than those of the control, and a decrement in pith thickness was observed less than control. As well as Intedhar and Majeed (2015) on two cultivars of pepper indicated that all seaweed extract concentrations used increased significantly the cortex thickness, the concentration of $6 \mathrm{ml} / \mathrm{l}$ gave the higher vascular cylinder thickness. In this concern, Sabh and Shallan (2008) studied stem cross sections of bean plants treated with seaweed extract and found that an increase in the thickness of; epidermis, cortex, paranchyma cells and pith size with increasing concentrations of extract used in 
comparison to non-treated plants. El-Desouky et al., (2011) and Akladious and Abbas (2013) mentioned that the use of a mixture of amino acids at different concentrations led to an increase in stem diameter of tomato as a result of increase in the thickness of epidermis and cortex as well as thickness of xylem, especially the number of vessels, compared to non-treated plants.

Table 5: Anatomical measurements $(\mu)$ of different tissues of $4^{\text {th }}$ terminal leaflet lamina of common bean plant $\mathrm{cv}$. Giza 6 aged 60 days as affected by mixture of $1 \mathrm{ml} / 1$ algae extract and $6 \mathrm{ml} / 1$ amino acid.

\begin{tabular}{|c|c|c|c|}
\hline Measurements & Control & $\begin{array}{c}1 \mathrm{ml} / \mathrm{l} \text { algae extract } \\
\text { with } 6 \mathrm{ml} / \mathrm{l} \text { amino acid. }\end{array}$ & \pm Control \\
\hline Stem diameter & 2715 & 3050 & +12.33 \\
\hline Cortex thickness & 148 & 165 & +11.48 \\
\hline Phloem tissue thickness & 78 & 105 & +34.61 \\
\hline Xylem tissue thickness & 240 & 268 & +11.66 \\
\hline Vessel diameter & 80 & 90 & +12.50 \\
\hline Pith diameter & 1470 & 1350 & -8.16 \\
\hline
\end{tabular}
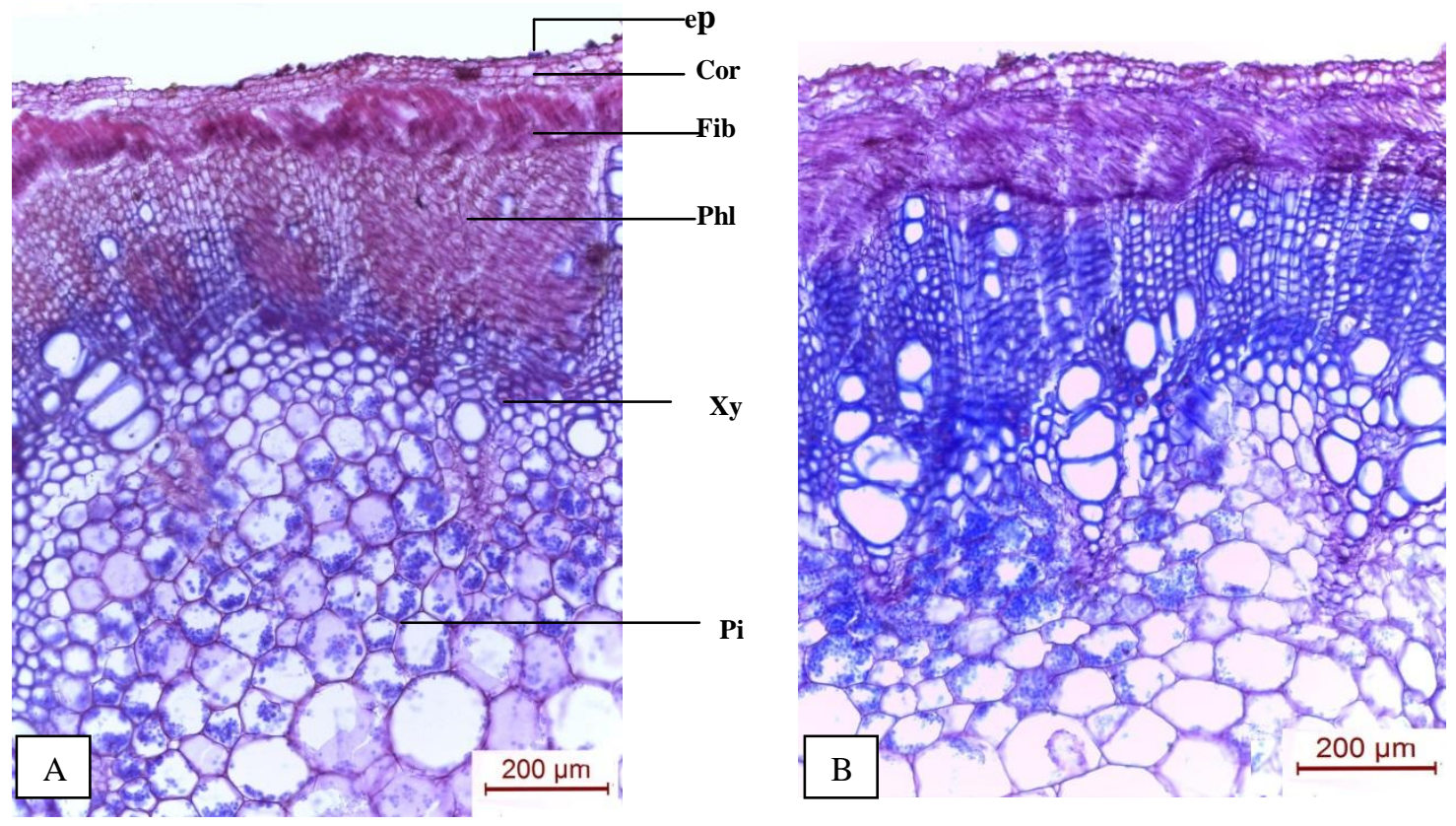

Fig. 1. Transverse sections through the $4^{\text {th }}$ internode of common bean plants at age of 60 days.

A. control plants

B. plants as affected by foliar spray with $6 \mathrm{ml} / 1$ amino acid mixed with $1 \mathrm{ml} / 1$ algae extract

Details: ep, epidermis; cor, cortex; fib, fibers; ph, phloem; xy, xylem and pi, pith.

(X100)

\section{b- Leaf anatomy}

Data presented in Table (6) and Figure (2) indicated that spraying $1 \mathrm{ml} / 1$ algae extract mixed with $6 \mathrm{ml} / 1 \mathrm{amino}$ acid on common bean cv. Giza 6 gave the highest increased in thickness of both midvein and lamina by 8.64 and $21.38 \%$ more control, respectively. The promotive effect of spraying $1 \mathrm{ml} / 1$ algae extract mixed with 6 ml/1 amino acid on leaf thickness due to an increase in palisade and spongy tissues by 8.91 and $70 \%$ compared to the control; respectively. Likewise, the vascular bundle of the midvein was increased in size as a result of spraying $1 \mathrm{ml} / 1$ algae extract mixed with $6 \mathrm{ml} / \mathrm{l}$ amino acid. The increment was $38.75 \%$ in length and it was $4.22 \%$ in width more than the control. In this respect, Salama and Yousef (2015) stated that spraying basil plant with seaweed extract at $1.5 \mathrm{ml} / \mathrm{l}$ increased thickness of both midvein and lamina of leaf and the increase in lamina thickness was accompanied with increments in thickness of palisade and spongy tissues compared with the control. Likewise, the main vascular bundle of the midvein was increased in length and width, moreover, xylem vessels increased in diameter more than the control. 
Table 6: Anatomical measurements $(\mu)$ of different tissues of median portion of $4^{\text {th }}$ internode of common bean plant cv. Giza 6 aged 60 days as affected by mixture of $1 \mathrm{ml} / 1$ algae extract and $6 \mathrm{ml} / \mathrm{l}$ amino acid.

\begin{tabular}{|l|c|c|c|}
\hline Measurements & Control & $\begin{array}{c}\mathbf{1 ~ m l / l} \text { algae extract } \\
\text { with 6 ml/l amino acid. }\end{array}$ & 土 Control \\
\hline Midvein thickness & 1643 & 1785 & +8.64 \\
\hline Lamina thickness & 173 & 210 & +21.38 \\
\hline Palisade tissue thickness & 101 & 110 & +8.91 \\
\hline Spongy tissue thickness & 50 & 85 & +70.00 \\
\hline Midvein bundle dimensions & & & \\
Length & 400 & 555 & +38.75 \\
Width & 355 & 370 & +4.22 \\
\hline
\end{tabular}

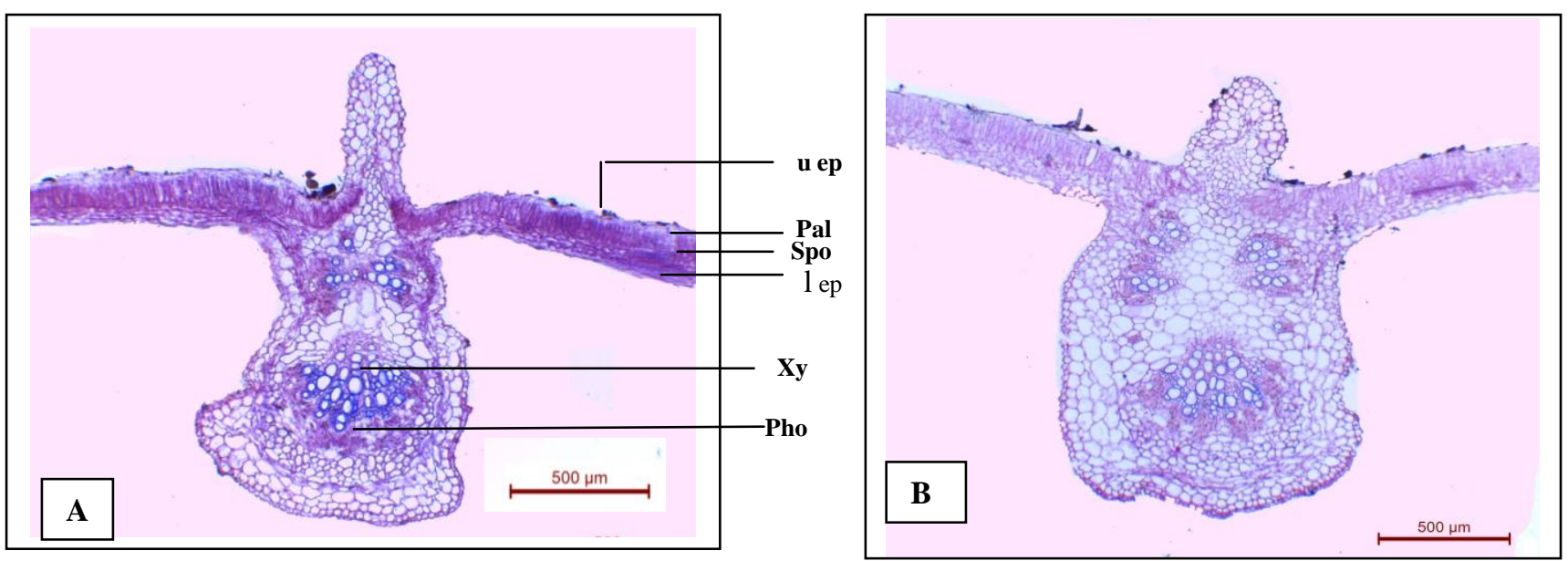

Fig. 2. Transverse sections through the blade of terminal leaflet of the compound leaf of common bean plants at age of 60 days.

A. control plants

B. plants as affected by foliar spry with $6 \mathrm{ml} / \mathrm{l}$ amino acid mixed with $1 \mathrm{ml} / \mathrm{l}$ algae extract.

Details: u ep, upper epidermis; pal, palisade tissue; spo, spongy tissue; 1 ep , lower epidermis; xy, xylem and Ph, phloem.

(X 40)

\section{References:-}

1. Abo Sedera, F.A., A.A. Abd El-Latif, L.A.A. Bader and S.M. Rezk (2010). Effect of NPK mineral fertilizer levels and foliar application with humic and amino acids on yield and quality of strawberry", Egypt. J. of Appl. Sci., 25: 154-169.

2. Abou El-Yazied, A., A.M. El-Gizawy, M.I. Ragab and E.S. Hamed (2012). Effect of seaweed extract and compost treatments on growth, yield and quality of snap bean", J. of Am. Sci., 8(6): 1-20.

3. Akladious, S.A. and S.M. Abbas (2013). Alleviation of seawater stress on tomato by foliar application of aspartic acid and glutathione. J. Stress Physiol. Biochem., 9: 282-298.

4. Boghdady M. S., Selim D. A. H., Nassar R. M. A. and Salama A. M. (2016). Influence of foliar spray with seaweed extract on growth, yield and its quality, profile of protein pattern and anatomical structure of chickpea plant (Cicer arietinum L.). Middle East J. Appl. Sci. 6, 207-221.

5. Csomos, E., and L. Simon-Sarkadi (2002). Characterisation of tokaj wines based on free amino acid and biogenic amine using ion-exchange chromatography. Chromatographia Supplement. 56:185-188.

6. Dhargalkar, V.K. and Pereira, N. (2005). Seaweed. Promising plant of the millennium. Scince.

7. Economou, G., D. Lyra, K. Sotirakoglou, K. Fasseas, and P. Taradilis (2007). Stimulating Orobanche ramose seed germination with an Ascophyllum nodosum extract. Phytoparasitica 35: 367-375.

8. El-Desouky, S.A., F.H. Ismaeil, A.L.Wanas, E-S. L. Fathy and M.M. AbdEl-All (2011). Effect of yeast extract, amino acids and citric acid on physio anatomical aspects and productivity of tomato plants grown in late summer season", Minufiya J. Agric. Res., 36(4): 859-884. 
9. El kaoua, M., Chernane, H., Benaliat, A. and Neamallah, L. (2013). Seaweed liquid extracts effect on Salvia officinalis growth, biochemical compounds and water deficit tolerance. African Journal of Biotechnology.

10. FAO. (2017). Food and Agriculture Organization of the United Nations. Faostat: Statistical Database.

11. Gomez, K.A. and A.A. Gomez (1984). Statistical procedures for agricultural research (2 ed.). John wiley and sons, NewYork, 680p.

12. Intedhar, A. M. and Majeed, K. A. (2015). Effect of Foliar Application of Seaweed Extract and Amino Acids on Some Vegetative and Anatomical Characters of Two Sweet Pepper (Capsicum annuиm L.) Cultivars. International Journal of Research Studies in Agricultural Sciences, 1(1): 35-44.

13. Kalidass, C., S. Jayarani and M. Glory (2010). Effect of seaweed liquid fertilizer on growth and biochemical constituents of Brassica nigra L. Int. J. Agri. Environ. Biotech. 3: 307-311.

14. Khan, W., Rayirath, U. P., Subramanian, S., Jithesh, M. N., Prasanth, R. P., Hodges, D. M., Critchley, A. T., Craigie, J. S., Norrie, J., Prithiviraj, B. (2009). Seaweed extracts as biostimulants of plant growth and development. Plant Growth Regulation, Berlim, 28 (4):386-399.

15. Kocira, A., Kornas, R. and Kocira, S.(2013). Effect assessment of Kelpak SL on the bean yield (Phaseolus vulgaris L.). J. Cent. Eur. Agr., 14: 67-76.

16. Kumar, G. and Sahoo, D. (2011). Effect of seaweed liquid extract on growth and yield of Triticum aestivum var. Pusa Gold. J. Appl. Phycol.,23(2): 251-255.

17. Latique, S., Chernane, H., Mansori, M. and El Kaoua, M. (2013). Seaweed liquid fertilizer effect on physiological and biochemical parameters of bean plant (Phaesolus vulgaris var. Paulista) under hydroponic system. Eur. Sci. J., 9(30): 174-191.

18. Lingakumar, K., D. Balasubramanian, S. K. G. Sundar, R. Jeyaprakash and M. Jeyakumar (2006). Effect of Ulva lactuca crude extract on growth and biochemical characteristics in Cyamopsis tetragonoloba $\mathrm{L}$. and Phaseolus mungo. Seaweed Res. Utiln. 28: 75-80.

19. Lingakumar, K., R. Jeyaprakash, C. Manimuthu and A. Haribaskar (2002). Gracilaria edulis- an effective alternative source as a growth regulator for Zea mays and Phaseolus mungo. Seaweed Res. Utiln. 24:117-123.

20. Nassar, M.A. and K.F. El-Sahhar (1998). Botanical Preparations and Microscopy (Microtechnique) . Academic Bookshop, Dokki, Giza, Egypt, pp : 219 (In Arabic).

21. Nour, K.A.M., N.T.S. Mansour and W.M. Abd El-Hakim (2010). Influence of foliar spray with seaweed extracts on growth, setting and yield of tomato during summer season, J. Plant Production, Mansoura University, 1(7): 961-976.

22. Öpik, H. and S. Rolfe (2005).The Physiology of flowering plants .Cambridge Univ. Pres 5. Plant Growth hormones pp:177-194.

23. Pise, N.M. and A.B. Sabale (2010). Effect of seaweed concentrates on the growth and biochemical constituents of Trigonella Foenum-Graecum L. J. Phytology, 2: 50-56.

24. Raverkar, K. P., Pareek, N., Chandra, R., Chauhan, S., Zodape, S.T. and Ghosh, A. (2016). Impact of foliar application of seaweed saps on yield, nodulation and nutritional quality in green gram (Vigna radiata $\mathrm{L}$.). Legume Res.,39(2): 315-318.

25. Rathore, S. S. R., G.N. Chaudhary, A. Boricha, B.P. Ghosh, S.T. Bhatt, J. Zodape and S. Patolia, (2009). Effect of seaweed extract on the growth, yield and nutrient uptake of Soybean (Glycine max) under rainfed conditions. South African Journal of Botany, 75:351-355.

26. Sabh A.Z. and Shallan M.A. (2008). Effect of organic Fertilization of Broad Bean (Vicia faba L.) by using different Marine Macro-algae in relation to the morphological characteristics and chemical constituents of the plant. Aust. J. Basic and Appl. Sci., 2(4 ):1076-1091

27. Salama, M. Azza and Rania S. Yousef (2015). Response of Basil Plant (Ocimum sanctum L.) to Foliar Spray with Amino Acids or Seaweed Extract. Journal of Horticultural Science \& Ornamental Plants, 7(3): 94- 106.

28. Salama, M. Azza, Attia, A.E. and Negm, M.S. (2016). Influence of foliar application with some biostimulants on growth, yield and Chemical composition of stevia plant (Stevia rebaudiana Bertoni). Middle East Journal of Agriculture Research, 5: 50-63.

29. Shalabia, S. E. (2011). Bioactive constituents of Atriplex halimus plant. Journal of Natural Products 4:25-41.

30. Shehata, S.A., Ahmed, Y.M., Emad, A.S. and Omaima S.D. (2011). Influence of Compost Rates and Application Time on Growth, Yield and Chemical Composition of Snap Bean (Phaseolus vulgaris L.) Australian Journal of Basic and Applied Sciences 5 (9), 530-536.

31. Zhang, X., Blair, M.W. and Wang, S. (2008). Genetic diversity of Chinese common bean (Phaseolus vulgaris L.) landraces assessed with simple sequence repeat markers. Theor. Appl. Genet. 117, 629-640.

32. Zodape, S. T., Kawarkhe, V. J., Patolia, J. S. and Warade, A. D. (2008). Effect of liquid seaweed fertilizer on yield and quality of Okra (Abelmoschus esculentus L.). 